DOI: 10.26693/jmbs05.01.246

UDC 614.253.4:371.83:159.9.07:37:378.124:614.258

Zemlyakova T. D., Holovkova T. A., Antonova O. V.

\title{
USING CHRONOBIOLOGICAL APPROACH FOR ASSESSING THE STUDENTS HEALTH STATUS FOR THE PURPOSE ITS PRESERVING
}

\author{
State establishment "Dnipropetrovsk Medical Academy of Health Ministry of Ukraine" \\ Department of General Hygiene, Dnepr city, Ukraine
}

TGolovkova@i.ua

The studying in higher education institution, young people face with a complex multifactorial environment of existence, adaptation to which depends on biorhythmological features. Future professional work of physicians and learning conditions demands from students the ability to overcome the stress, an adequate level of personal stress resistance, which is determined by peculiarities of a person's nervous and mental state, his/her ability to take responsibility for the result in an irregular situation.

The purpose of the work was to determine the type of working capacity and establishing the degree of stress exposure in medical students for developing a complex of prophylactic activities for students' adaptation to difficult training conditions and improvement of its quality.

Material and methods. Biorhythmological peculiarities of 78 boys and 214 girls were analyzed. Using special questionnaire we determined the types of biorhythms (disability) and exposure to stress in the third year students of the Dnepropetrovsk Medical Academy.

Results and discussion. Research results testified that the majority of students (47\%) were doves, almost one third of them (30\%) were larks, and $23 \%$ of respondents accounted for owls. "Doves" had the increased adaptation capability compared with the most diverse types. The fact that most boys and girls (42\% and $51 \%$, respectively) were arrhythmic was very positive, taking into account the particularities of doctors' work. The obtained results showed that the most adaptable to stress respondents were «larks» ( $p<0.01$ ), although it did not coincide with the results of similar questionnaires.

Other authors' research results evidenced that stress resistance depended not only on the brain functional activity, but also on functional states of the organism, mental activity, working capacity, social states and other. $31 \%$ of respondents were resistant to stress, $67 \%$ had moderate predisposition to stress, and increased sensitivity to stress factors was typical for $2 \%$ of students. Manifestations of psychosomatic disorders were fixed in $67.5 \%$ of young people.
Conclusion. The obtained data allowed analyzing the proportion of boys and girls biorhythms types, to describe their gender characteristics, the degree of emotional tension as well as the opportunity to develop activities for desynchronoses prevention, resistance to stress factors, increasing and preserving students' health.

Keywords: types of biorhythms, pigeons, larks, owls, students.

Research relation to the plans, programs and department themes. The study was carried in accordance with the research plan "Comprehensive hygienic assessment of the working environment and working conditions of workers at enterprises of different profiles and their influence on the health of workers"; the state registration number is $0115 \mathrm{U} 001086$.

Introduction. In recent years, significant changes have taken place in the society of our country, under which the youth assumes more responsibilities of adults, feels more responsible for the quality of education as the basis of their future. The well-being of the person, his/her ability to mental, creative and physical work, harmonious perception of the world largely depend on the mode of work and rest fits the individual biorhythms of the person [1]. Knowledge of the features of biological rhythms is also of great importance for the active practical activity of man, especially in the field of medicine [2, 3].

Taking into account the individual characteristics of biological rhythms, you can choose the most comfortable period for effective work or training and predict negative changes in the biological system [4]. Data on the features of students' biorhythms will allow ensuring conditions of harmonious development and efficiency of the educational process. Researches of scientists of the last decades proved that the use of a chronobiological approach to assessing students' health status in order to preserve health, is one of the urgent problems of psychohygiene today [5, 6].

At the same time, human factors of the environment violate the internal rhythm, which leads to 
disorders of the body in the short or long term. In today's society and the active pace of life, many desynchronizing factors, including stressors (psychological stress, intellectual load), affect negatively the psychoemotional sphere of a person. For the most part, stress is an integral part of our lives, it is simply impossible to avoid, but it is necessary to be able to overcome the effects of excessive stress [7, 8]. G. Selee stated: "You should not be afraid of stress. Only dead people do not have it. Stress should be managed, and then you will feel the aroma and taste of life".

Individual stress resistance is determined to a large extent by the features of the psycho-emotional state of the person, its abilities to take responsibility for the situation. Studying in a higher medical institution constitutes, on the one hand, a considerable part of full self-realization, on the other hand, in the conditions of intensity of educational process, can negatively affect the completely unformed body of boys and girls [9]. Therefore, an important psycho-hygienic aspect of the work of the educational institution is the prognosis of social adaptation of students, the assessment of the resources of the individual needed to overcome difficulties, the ability to create an individual program of training using methods of counteracting stress $[10,11]$.

The above issues require an integrated approach to ensuring a healthy lifestyle and enhancing student performance by optimizing biorhythms and preventing the occurrence of psychosomatic disorders and illnesses associated with stress conditions.

All experiments were conducted in accordance with the Council of Europe Convention "On the Protection of Human Rights and Dignity of the Human Being with regard to the Application of Biology and Medicine Application of Biological and Medicine Achievements (ETS No. 164)" dated 04.04.1997, and the Helsinki Declaration of the World Medical Association (2008). Each patient signed an informed consent to participate in the study and all measures to ensure anonymity of patients were taken.

The purpose of the work was to study the biorhythmic characteristics of medical students, determine their type of performance during intensive training and establish the degree of stress exposure to develop a set of preventive measures that will help to maintain students' health.

Material and methods of research. At the preparatory stage, the status of the problem was studied by the processing of numerous literary sources. The studies involved 292 students of the third course of medical faculties of Dnipropetrovsk Medical Academy (78 boys and 214 girls). The type of youth biorhythm ("larks", "doves", "owls") was determined by O. Ostberg's method of modification by S. Stepanova [6].
The degree of susceptibility to stress was determined by questionnaire. 584 questionnaires were processed using traditional statistical methods.

Results. Data analysis allowed us to determine the types of students' biorhythms. We found out that most of them had arrhythmia (47\%), in the second place was the morning type of working capacity which comprised $30 \%$, in the third was the evening type with $23 \%$ of respondents. This distribution is the most positive not only from the physiological features of "doves", which are equally successfully adapted to any daily regime, but also meets the requirements of professional selection for a doctor.

Describing the gender peculiarities of student distribution by types of biorhythms, it should be noted (Table) that the percentage of arrhythmias, both boys and girls was $51 \%$ which coincided with the highest percentage on average comprising $47 \%$, and the distribution of students by other types of performance differs by 1.5-1.3 times depending on gender: 41-26 $\%$ were "larks" and 17-23 \% were "owls" (boys and girls, respectively).

Table - Results of studying type in students

\begin{tabular}{l|c|c|c|c}
\hline \multirow{2}{*}{ Sex } & \multicolumn{3}{|c|}{ Type biorhythm, abs. (\%) } & \multirow{2}{*}{$\begin{array}{c}\text { The } \\
\text { whole, } \\
\text { abs. (\%) }\end{array}$} \\
\cline { 2 - 4 } & «larks» & «pigeons» & «owls» & (13) \\
\hline boys & $32(41)$ & $33(42)$ & $13(17)$ & $78(100)$ \\
\hline girls & $56(26)$ & $109(51)$ & $49(23)$ & $214(100)$ \\
\hline The whole & $88(30)$ & $142(47)$ & $62(23)$ & $292(100)$ \\
\hline
\end{tabular}

When evaluating the response of the interviewees to the effect of emotional factors it was found that one third of medical students were stress resistant (31\%), but the majority of respondents $(67 \%)$ had a moderate sensitivity to psychogenic factors and only 6 students (2\%), had a high level tendency to stress.

Different rhythm of performance, which characterizes the representatives of morning, day and evening types, take place due to certain features of the hormonal and mental spheres of the body, which are embedded in the genetic program and additionally formed during life under the influence of various factors. Therefore, it was interesting to analyze the influence of psychogenic factors on the body of a young person on the manifestation of symptoms of psychosomatic disorders (feelings of chronic fatigue, insomnia, psychoalgia, etc.). Taking into account the questionnaire we saw that on average $67.5 \%$ of the surveyed students had psychosomatic disorders like "weak links" in the system of adaptive reactions of the organism to the current conditions of existence.

$83 \%$ of the young people in the observation group with a high tendency to stress reported having a variety of psychosomatic disorders. The highest 
proportion of students (196 out of 292 surveyed) with a moderate tendency to stress in $76 \%$ of cases felt the impact of stress on the deterioration of well-being, as did $50 \%$ of respondents with a low degree of stress.

\section{Some points from the general conclusion:}

- Some "doves" had the increased adaptable capability of the organisms compared with the most diverse types $[1,2,3]$. The fact that most boys and girls (42\% and $51 \%$, respectively) were arrhythmic was very positive, taking into account the particularities of doctors' work (night and day duty, shift work, unplanned performance of various types of professional activity, etc.).

- The obtained results showed that the most adaptable to the stress respondents were "larks" ( $p<0.01$ ), but it did not coincide with the results of similar questionnaires. Other authors' results evidenced that stress resistance depended not only from of functional activity of the brain, but also on functional states of the organism, mental activity, working capacity, social states and other $[4,8]$.

- An important factor for the professional selection of future physicians is the presence of a small proportion of them with the highest level of sensitivity to psychogenic factors which was only $2 \%[1,6]$.

- The sufficiently high level of psychosomatic disorders in the $3^{\text {rd }}$ year students can be explained by the peculiarities of the study programs, the length of the intense educational process in the university, the quality of living and socio-economic conditions of life $[2,7]$.

\section{Conclusion}

1. The study revealed that $47 \%$ of students belonged to full-time work capacity. The distribution of types of biorhythms in boys and girls had the same rank (relative values): "doves" - "larks" - "owls". According to the nature of biorhythms among students, the number of "doves" and "larks" was almost the same (42 and $41 \%$ respectively), and owls made up $17 \%$ of respondents. Among arrhythmic female students, more than half $(51 \%)$ and morning and evening work capacity had almost the same proportion $-26 \%$ and $23 \%$, respectively.

2. One-third of students (31\%) were stress-resistant, most $(67 \%)$ of them had a moderate tendency to stress, and a high sensitivity to stress factors was characteristic of only $2 \%$ of students (6 respondents). Among the boys in the observation group, $38 \%$ were stress-resilient, the least likely to respond to stress were the lark boys. About $80 \%$ of girls of all types of working ability had a moderate tendency to stress, while at the same time the most resistant to stress were also larks. Only $1.4 \%$ of girls who had no relation to individual biorhythm have the highest sensitivity to psycho-traumatic factors.

3. Symptoms of psychosomatic disorders occupied a significant proportion of young people $(67.5 \%)$ who participated in the research. Characteristic complaints of well-being were reported for most students with moderate stress and practically all students with a high tendency.

Perspective for further research. The results of applying a chronobiological approach to the assessment of the health status of modern student youth, taking into account gender differences, peculiarities of emotional state, the level of subjective control will further develop methodical guidelines for harmonization of biorhythms and prevention of desynchronosis, in order to preserve psychosomatic health.

\section{References}

1. Hildebrandt G, Moser M, Lehofer M. Chronobiology and chronomedicine. M: Arnebia; 2006. 144 p.

2. Sergeet IV. The fundamental basis for evaluating the processes of overcoming the psychophysiological and psychological adaptation of the most current students and students. Dovkillya i zdorovya: materials of the All-Ukrainian scientific-practical conference. Ternopil; 2011. p. 115-6.

3. Goncharenko MS, Timchenko GM. Korelyatsiyna the structure of indicators of the functional camp of the organism systems in the highest and the last groups. Pedagogy, psychology and medical and biological problems of physical and sports. 2007; 9: 36-43.

4. Korolchuk VM. Stressost and adaptive potential of specialness in stresogenous minds News of the Chernigiv National Pedagogical University. 2010; 82(I): 126-36.

5. Khoromsky LM, Svistun RV. Organizational organisms of people. Ternopil: TDMU Ukrmedkniga; 2005. 220 p.

6. Timchenko GM. Chronobiologichesky pidkhid schodo otsinki I will become healthy's students. News of the Kharkiv National University, named after VN Karazin. Seriya: Biology. 2011; 13(947): 190-5.

7. Zolotnikova GP, Zakharova MV. Methodological approaches to increasing the level of mental adaptation, stress resistance of students in modern conditions: a teaching. Bryansk: Beloberezhye; 2018. 54 p.

8. Stepova AS. Psychological features of stress resistance of adolescents. Young Scientist. 2018; 9(61): 314-9.

9. Sikorska LB, Vovk LP, Volotovskaya YaV. Psychological conditions of stress resistance of future specialists of the special education system. Young Scientist. 2017; 5(45): 223-6.

10. Mezentsev SA. Chronobiological approach, as a method of objective prediction of human adaptation. Materials of the International Symposium "Ecological and physiological problems of adaptation." Moscow, 2003. 2003: 355-6.

11. Roenneberg T, Wirz-Justice A, Merrow M. Life between cloks: Daily Temporal Patterns of Human Chronotypes. $J$ of Biological rhythms. 2003; 18(1): 18-29. PMID: 12568247. doi: 10.1177/0748730402239679 
Удк 614.253.4:371.83:159.9.07:37:378.124:614.258

ЗАСТОСУВАННЯ ХРОНОБІОЛОГІЧНОГО ПІДХОДУ ЩОДО ОЦІНКИ

СТАНУ ЗДОРОВ'Я СТУДЕНТІВ 3 МЕТОЮ ЙОГО ЗБЕРЕЖЕННЯ

Землякова Т. Д., Головкова Т. А., Антонова О. В.

Резюме. В процесі навчання у вищому медичному закладі молода людина стикається зі складним багатофакторним середовищем, адаптація в якому залежить, у тому числі і від біоритмологічних особливостей. Майбутня професія та умови навчання вимагають від студентів вміння долати стреси та достатнього рівня індивідуальної стресостійкості, яка визначається значною мірою особливостями психоемоційного стану людини, її можливостями взяти на себе відповідальність за ситуацію, що склалася.

У зв'язку з цим, метою роботи є визначення типу працездатності та встановлення ступеню схильності до стресу студентів медиків для розробки комплексу профілактичних заходів адаптації студентства до складних умов навчання та підвищення його якості. За допомогою анкетування встановили типи біоритмів (працездатності) у 292 студентів III курсу Дніпропетровської медичної академії (78 юнаків та 214 дівчат), а також ступінь їх схильності до стресу. Результати досліджень біоритмологічних особливостей свідчать, що найбільша частка студентів (47\%) - аритміки, ранковий тип складає майже третину респондентів (30\%), а вечірній тип працездатності має меншість (23\%). Ураховуючи особливості праці лікарів (нічні та добові чергування, змінність роботи, позапланове виконання різних видів професійної діяльності, тощо) встановлений факт того, що більшість юнаків і дівчат аритміки, відмічений як позитивний. 31\% опитаних стресостійкі, 67\% мають помірну схильність до стресу, підвищена чутливість до стресових чинників характерна для $2 \%$ студентів. Прояви психосоматичних розладів мають 67,5\% молоді. Аналіз даних дав можливість проаналізувати питому вагу типів біоритмів юнаків та дівчат, охарактеризувати їх гендерні особливості, ступінь емоційного напруження на тлі перенавантаження навчального процесу та розробити комплекс заходів щодо профілактики десинхронозів, підвищення стресостійкості задля збереження здоров'я студентства.

Ключові слова: типи біоритмів, голуби, жайворонки, сови, студенти.

Удк 614.253.4:371.83:159.9.07:37:378.124:614.258

ИСПОЛЬЗОВАНИЕ ХРОНОБИОЛОГИЧЕСКОГО ПОДХОДА ДЛЯ ОЦЕНКИ

СОСТОЯНИЯ ЗДОРОВЬЯ СТУДЕНТОВ С ЦЕЛЬЮ ЕГО СОХРАНЕНИЯ

Землякова Т. Д., Головкова Т. А., Антонова Е. В.

Резюме. В процессе обучения высшем учебном заведении молодые люди сталкиваются со сложной многофакторной средой существования, адаптация в которой зависит, в том числе и от биоритмологических особенностей. Будущая профессиональная деятельность медиков и условия обучения требует от студента умения преодолевать стресс, достаточного уровня индивидуальной стрессоустойчивости, которая определяется в большей степени особенностями нервно-психического состояния человека, его возможностью взять на себя ответственность за результат в нестандартной ситуации.

В связи с этим цель роботы - определения типа трудоспособности и установление степени подверженности стрессу студентов медиков для разработки комплекса профилактических мероприятий по адаптации студенчества в сложных условиях обучении и повышения его качества. Проанализированы данные биоритмологических особенностей у 78 юношей и 214 девушек. С помощью анкетирования определили типы биоритмов (трудоспособности) у студентов III курса Днепропетровской медицинской академии, а также степень подверженности их стрессу. Результаты исследований свидетельствуют, что большинство студентов (47\%) - голуби, жаворонков почти треть (30\%), а совы составляют 23\% респондентов. Учитывая особенности труда врачей (ночные и суточные дежурства, сменность работы и т.д.), установленный фракт того, что большинство юношей и девушек аритмики, отмечен как положительный. $31 \%$ опрошенных стрессоустойчивые, 67\% имеют умеренную склонность к стрессу, повышенная чувствительность к стрессу характерна для $2 \%$ студентов. Анализ данных дал возможность проанализировать удельный вес типов биоритмов юношей и девушек, охарактеризовать их гендерные особенности, степень эмоционального напряжения и разработать комплекс мер по профилактики десинхронозов, повышению сопротивляемости стрессовым факторам и сохранению здоровья студентов.

Ключевые слова: типы биоритмов, голуби, жаворонки, совы, студенты.

The authors of this study confirm that the research and publication of the results were not associated with any conflicts regarding commercial or financial relations, relations with organizations and/or individuals who may have been related to the study, and interrelations of coauthors of the article.

Стаття надійшла 02.08.2019 р. Рекомендована до друку на засіданні редакційної колегії після рецензування 